\title{
Modern Synthetic Approaches to Phthalonitriles with Special Emphasis on Transition-Metal Catalyzed Cyanation Reactions
}

\author{
Alexander G. Martynov, ${ }^{a}{ }^{\circ}$ Kirill P. Birin, $^{\mathrm{a}}{ }^{\text {Yulia G. Gorbunova }}{ }^{\mathrm{a}, \mathrm{b}}$ \\ and Aslan Yu. Tsivadze ${ }^{a, b}$ \\ Dedicated to Full member of Russian Academy of Sciences, Prof. I. P. Beletskaya \\ on the occasion of her Anniversary
}

\begin{abstract}
${ }^{a}$ A.N. Frumkin Institute of Physical Chemistry and Electrochemistry, Russian Academy of Sciences, 119071 Moscow, Russia ${ }^{\mathrm{b}}$ N.S. Kurnakov Institute of General and Inorganic Chemistry, Russian Academy of Sciences, 119991 Moscow, Russia

${ }^{\circledR}$ Corresponding author E-mail: martynov.alexandre@gmail.com
\end{abstract}

\begin{abstract}
Series of substituted phthalonitriles (4,5-bis[2'-(2"-benzyloxyethoxy)ethoxy]phthalonitrile, 4,5-bis(2-ethoxyethoxy) phthalonitrile and 4',5',4",5"-tetracyanodibenzo-24-crown-8) was obtained by means of Pd-catalyzed cyanation reaction in high yields. Analysis of the obtained results together with previously reported data concerning transition metal catalyzed synthesis of phthalonitriles and analogues reveals advantages of each of these methods in comparison with classical approaches - ammonolysis/dehydratation and Rosenmund-Braun cyanation.
\end{abstract}

Keywords: Phthalonitriles, transition metal catalyzed cyanation, Rosenmund-Braun reaction, alkoxy sustituted phthalonitriles, tetracyanodibenzo-24-crown-8.

\section{Современные методы синтеза фталонитрилов: особенности применения реакций металлокомплексного катализа}

\author{
А. Г. Мартынов ${ }^{a} @$ К. П. Бирин, ${ }^{a}$ Ю. Г. Горбунова, ${ }^{a, b}$ А. Ю. Цивадзе ${ }^{a, b}$ \\ Посвящается Акаgемику РАН,профессору И.П. Белецкой по случаю ее юбилея \\ ${ }^{\mathrm{a}}$ ФББУН Институт физической химии и электрохимии им. А.Н. Фрумкина Российской Академии Наук, 119071 \\ Москва, Россия \\ ${ }^{\mathrm{b}}$ ФББУН Институт общей и неорганической химии им. Н.С. Курнакова Российской Академии Наук, 119991 Москва, \\ Россия \\ ${ }^{\circledR}$ E-mail: martynov.alexandre@gmail.com
}

\begin{abstract}
Серия замещенных фтталонитрилов (4,5-бис[2'-(2"-бензилоксиэтокси)этокси]фталонитрил, 4,5-бис(2этоксиэтокси) фталонитрил и 4',5',4",5"-тетрачианодибензо-24-краун-8) была получена с высокими выходами c применением реакции Pd-катализируемого циианирования. Проведен анализ полученных результатов и их сравнение с ранее опубликованными данными по синтезу фталонитрилов с использованием реакиий цианирования, катализируемых комплексами переходных металлов. Это позволило продемонстрировать преимущеества данных методов по сравнению с классическими методами синтеза фталонитрилов - реакций аммонолиза/дегидратации и ичианирования по Розенмунду-Брауну.
\end{abstract}

Ключевые слова: Фталонитрилы, цианирование с использованием металлокомплексного катализа, реакция Розенмунда-Брауна, алкокси-замещенные фталонитрилы, тетрацианодибензо-24-краун-8. 


\section{Introduction}

Continuously growing interest in functional materials, based on phthalocyanines and related macrocycles requires efficient methodologies for preparation of their precursors. Aromatic $o$-dinitriles (phthalonitriles and analogues) are the most applied precursors, used for the preparation of phthalocyanines. ${ }^{[1-4]}$ The properties of these macrocycles are crucially influenced by the nature of the peripheral substituents, therefore synthesis of appropriately substituted phthalonitriles is an important task. ${ }^{[5]}$ Two major synthetic approaches towards substituted phthalonitriles have been developed and widely applied - modification of phthalic acid derivatives via ammonolysis and dehydratation reactions (Figure 1) and cyanation of $o$-dibromides by copper(I) cyanide (Rosenmund-Braun reaction) (Figure 2). Each approach has its own advantages and drawbacks.

The first approach suggests stepwise transformations of phthalic acid derivatives (typically, anhydrides), yielding phthalimides and phthalamides after first and second ammonolysis steps respectively (Figure 1 $i$, ii). Dehydrataion of phthalamides yields target phthalonitriles (Figure 1iii).
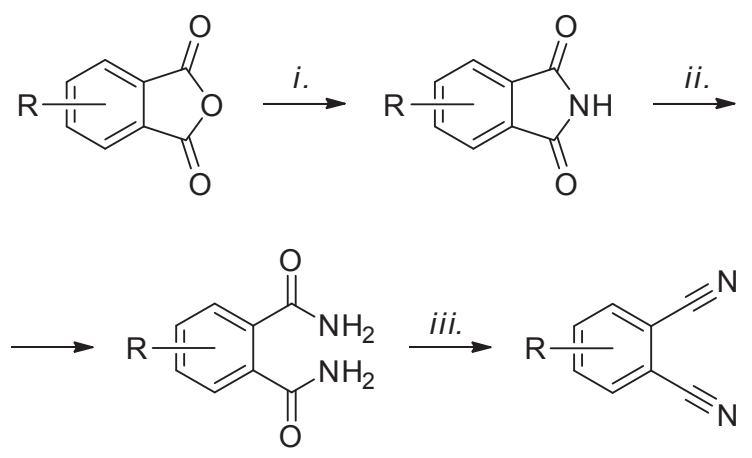

Figure 1. Ammonolysis and dehydratation of phthalic acid derivatives, leading to phthalonitrile: $i$. fusing with urea or reflux in formamide; ii. conc. $\mathrm{NH}_{4} \mathrm{OH}$; iii. dehydrating agent $-\mathrm{POCl}_{3}$, or $\mathrm{SOCl}_{2}$, or $(\mathrm{COCl})_{2}$, or $\left(\mathrm{CF}_{3} \mathrm{CO}\right)_{2} \mathrm{O}$, etc.

Although the procedure is multistep, each of subsequent reactions is typically characterized by high yields and high purity of the products, which can be isolated by simple filtration without any additional chromatography. This method was successfully applied for the preparation of phthalonitriles, bearing relatively inert functional groups (halogens,,${ }^{[6,7]}$ nitro-,${ }^{[8,9]}$ silyl-groups,${ }^{[10]}$ polyether chains, ${ }^{[11]}$ etc.). However, highly reactive compounds, which are used to perform dehydratation step (acetic anhydride, thionyl chloride, oxalylchloride, etc.), limit application of this method for the preparation of phthalonitriles with labile substituents.

The one-step reaction of $o$-dibromides with $\mathrm{CuCN}$ (Figure 2), typically performed in refluxing $N, N$ dimethylformamide is the most widely used second approach towards phthalonitriles, bearing various functional groups, affording large number of dicyanated arenes, heteroarenes ${ }^{[5]}$ and even porphyrins. ${ }^{[12]}$ However, this method also has its own limitations, originating mostly from harsh reaction conditions.

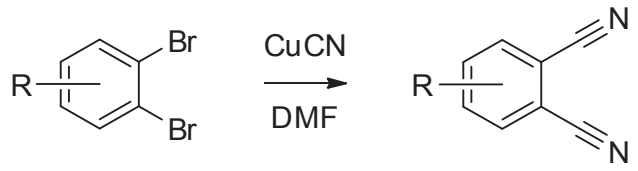

Figure 2. Rosenmund-Braun reaction.

Substitution of one bromine atom the first step is relatively fast, but upon insertion of one cyano-group, the reactivity of the resulting $o$-bromo-cyanoarene decreases drastically. ${ }^{[13]}$ It slows down the rate of the second substitution step, therefore, prolonged reflux of the reaction mixture is required to improve conversion (typically, for 6-18 hours). Decrease of reaction time results in contamination of resulting phthalonitrile by product of mono-substitution. The later acts as inhibitor of cyclotetramerization step in synthesis of phthalocyanines, which was demonstrated on the example of cyanation of 4',5'-dibromobenzo-15-crown-5. ${ }^{[14]}$

On the other hand, increase of reaction time facilitates undesired side processes, mainly consumption of the resulting phthalonitrile by $\mathrm{Cu}$-templated synthesis of copper(II) phthalocyaninate, as well as formation of benzonitriles because of reductive dehalogenation of intermediate $o$-bromo-cyanoarene. ${ }^{[15]}$ Moreover, this reaction fails to produce dinitriles when the substituents in aromatic ring contain proton-donating groups and coordinating atoms, which can form complexes with $\mathrm{Cu}^{\mathrm{I}}$ ions. In these cases, the introduction of protective groups is required, ${ }^{[15-18]}$ but even these precautions sometimes do not guarantee high yields of Rosenmund-Braun cyanation of certain substrates. ${ }^{[19]}$

In course of reaction, the resulting phthalonitrile forms complexes with $\mathrm{Cu}^{\mathrm{I}}$ ions, which should be decomposed to release target compound. For this purpose, oxidative cleavage is applied, by prolonged treatment of reaction mixture with conc. $\mathrm{NH}_{4} \mathrm{OH}$ in air, or by reaction with aqueous $\mathrm{FeCl}_{3} \cdot{ }^{[18,20]}$ Target free phthalonitrile is extracted and/or filtered from the resulting mixture. Obviously, this process lead to the formation of significant amounts of heavy metal waists.

Taking into account these drawbacks and limitations, different research groups tried to improve Rosenmund-Braun cyanation. For example, Barrett et al. used activation of $o$-dichlorobenzene via the formation of chromium $\pi$-complex (Figure 3). ${ }^{[21]}$ Prior to cyanation, starting substrate was treated with chromium hexacarbonyl yielding (o-dichlorobenzene) tricarbonylchromium. Its reaction with $\mathrm{K}^{13} \mathrm{CN}$ in DMSO in the presence of 18 -crown- 6 and subsequent photoinduced airoxidation gave labeled $o-\left({ }^{13} \mathrm{CN}\right)_{2} \mathrm{C}_{6} \mathrm{H}_{4}$ in $63 \%$ yield. However, this approach was never widely spread afterwards.

One can expect, that the surveys for novel efficient approaches towards phthalonitriles could lead to wide utilization of catalytic reactions. However, by the moment, there are only few papers which study transition metal catalyzed preparation of $o$-dinitriles notwithstanding that synthesis of mono-cyanoarenes is one of the most explored classes of transition-metal catalyzed reactions. ${ }^{[22-24]}$

The goal of the present paper is analysis of reported examples of catalytic preparation of phthalonitriles as well as description of recent advances of our group in preparation of precursors to functionalized phthalocyanines via $\mathrm{Pd}$ catalyzed cyanation reaction. 


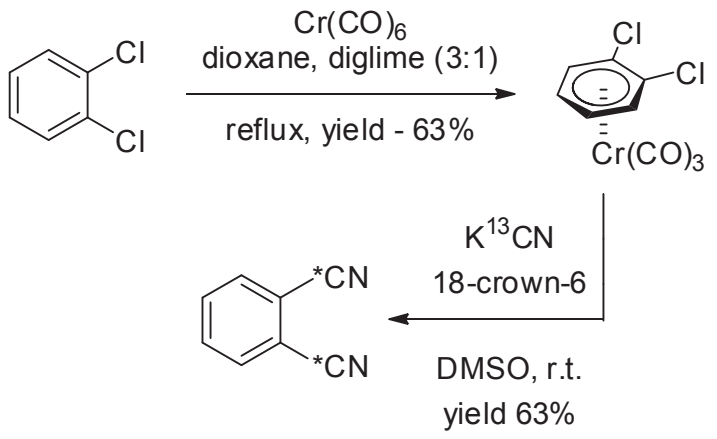

Figure 3. Synthesis of ${ }^{13} \mathrm{C}$-labeled phthalonitrile via activation of $o$-dichlorobenzene. ${ }^{[21]}$

\section{Experimental}

Catechol, chloroethoxyethanol, ethoxyethanol, tosylchloride, $\mathrm{N}$-bromosuccinimide (NBS), zinc cyanide, dipalladium tric(dibenzalacetone) - $\operatorname{Pd}_{2}(\mathrm{dba})_{3}, \quad 1,1$ '-diphenylphosphinoferrocene (dppf), polymethylhydrosiloxane (PMHS) available from commercial suppliers (Aldrich, Merck) were used without further purification. The solvents $\left(\mathrm{CHCl}_{3}\right.$, EtOAc, hexane) were distilled over $\mathrm{CaH}_{2} . \mathrm{N}, \mathrm{N}$-Dimethylformamide - DMF (Aldrich, $\geq 98.0 \%$ ) and $N, N$-dimethylacetamide - DMAA (Aldrich, $\geq 99 \%$ ) were used as received without further purification. 1,2-Dibromo-4,5-bis[2"(2'-hydroxyethoxy)ethoxy]benzene 1a, 1,2-dicyano-4,5-bis[2"(2'-hydroxyethoxy)ethoxy] benzene $\mathbf{1 b},{ }^{[25]}$ 1,2-dibromo-4,5-bis[2"(2'-benzyloxyethoxy)ethoxy]benzene $\mathbf{2 a},{ }^{[16]}$ were synthesized as reported elsewhere. NMR spectra were recorded on Bruker Avance 600. NMR spectra were referenced on residual solvent signal. ${ }^{[26]}$

4,5-Bis [2'-(2"-benzyloxyethoxy)ethoxy]phthalonitrile (2b). 1,2-Dibromo-4,5-bis[2'-(2"-benzyloxyethoxy)ethoxy]benzene $\mathbf{2 a}$ $(500 \mathrm{mg}, 0.8 \mathrm{mmol})$ was dissolved in $2 \mathrm{ml}$ of DMAA, $\mathrm{Pd}_{2}(\mathrm{dba})_{3}$ (15 mg, $16 \mu \mathrm{mol})$, dppf (12 mg, $22 \mu \mathrm{mol})$ and PMHS $(20 \mathrm{mkl})$ were added and the mixture heated to $120^{\circ} \mathrm{C}$. Solid $\mathrm{Zn}(\mathrm{CN})_{2}(141$ $\mathrm{mg}, 1.2 \mathrm{mmol}$ ) was added portionwise during first $1.5 \mathrm{~h}$ and heating was continued for 1.5 more $\mathrm{h}$. Then reaction mixture was cooled to r.t., filtered and the filtrate was evaporated. Resulting brown oil was chromatographed on silica, elution with $\mathrm{CHCl}_{3}+3 \mathrm{vol} . \%$ $\mathrm{MeOH}$ and evaporation afforded dinitrile $2 \mathrm{~b}$ as yellowish oil (336 $\mathrm{mg}$, yield $81 \%$ ). NMR spectra of $\mathbf{2} \mathbf{b}$ coincide with the previously reported data. ${ }^{[16]}{ }^{1} \mathrm{H}$ NMR $\left(600 \mathrm{MHz}, \mathrm{CD}_{2} \mathrm{Cl}_{2}\right) \delta_{\mathrm{H}}$ ppm: 7.31-7.27 $\left(\mathrm{m}, 10 \mathrm{H}, \mathrm{H}^{\mathrm{Bn}}\right) ; 7.23\left(\mathrm{~s}, 2 \mathrm{H}, \mathrm{H}^{\mathrm{Ar}}\right) ; 4.51\left(\mathrm{~s}, 4 \mathrm{H}, \mathrm{CH}_{2}^{\mathrm{Bn}}\right) ; 4.20,3.86$, 3.70, $3.62\left(4 \mathrm{~m}, 4 \times 4 \mathrm{H}, \mathrm{OCH}_{2}\right) .{ }^{13} \mathrm{C}$ NMR $\left(100 \mathrm{MHz}, \mathrm{CD}_{2} \mathrm{Cl}_{2}\right) \delta_{\mathrm{C}}$ ppm: 152.3, 138.4, 128.3, 127.6, 116.7, $115.9(\mathrm{CN}), 108.7(\mathrm{CCN})$, 73.1, 70.9, 69.6, 69.4, 69.2.

2-Ethoxyethyl 4-methylbenzenesulfonate (3a). Solution of $\mathrm{NaOH}(14.00 \mathrm{~g}, 0.35 \mathrm{~mol})$ in $50 \mathrm{ml}$ of $\mathrm{H}_{2} \mathrm{O}$ was mixed with the solution of 2-ethoxyethanol $(9.70 \mathrm{ml}, 0.10 \mathrm{~mol})$ in $100 \mathrm{ml}$ of THF and the mixture was cooled to $0{ }^{\circ} \mathrm{C}$ under vigorous stirring. The solution of TsCl $(24.78 \mathrm{~g}, 0.13 \mathrm{~mol})$ in $70 \mathrm{ml}$ of THF was added dropwise and the mixture was stirred overnight. After neutralization with aqueous $\mathrm{HCl}$, the mixture was extracted with $\mathrm{CHCl}_{2}(3 \times 100$ $\mathrm{ml}$ ), the organic layers were washed with brine, dried over $\mathrm{Na}_{2} \mathrm{SO}_{4}$ and evaporated to give the target tosylate $\mathbf{3} \mathbf{a}$ as a clear liquid (14.52 $\mathrm{g}, 60 \%$ ). It was used for the next step without additional purification. ${ }^{1} \mathrm{H}$ NMR $\left(600 \mathrm{MHz}, \mathrm{CDCl}_{3}\right) \delta_{\mathrm{H}} \mathrm{ppm}: 1.13\left(\mathrm{t}, J=7.0 \mathrm{~Hz}, 3 \mathrm{H}, \mathrm{CH}_{3}{ }^{\mathrm{Et}}\right)$, $2.44\left(\mathrm{~s}, 3 \mathrm{H}, \mathrm{CH}_{3}{ }^{\mathrm{Ts}}\right), 3.45\left(\mathrm{q}, J=7.0 \mathrm{~Hz}, 2 \mathrm{H}, \mathrm{OCH}_{2}{ }^{\mathrm{Et}}\right), 3.59-3.62(\mathrm{~m}$, $\left.2 \mathrm{H},-\mathrm{OCH}_{2} \mathrm{CH}_{2} \mathrm{OEt}\right), 4.14-4.17\left(\mathrm{~m}, 2 \mathrm{H},-\mathrm{OCH}_{2} \mathrm{CH}_{2} \mathrm{OEt}\right), 7.33$ (d, $\left.J=8.1 \mathrm{~Hz}, 2 \mathrm{H}, m-\mathrm{H}^{\mathrm{Ts}}\right), 7.80\left(\mathrm{~d}, J=8.1 \mathrm{~Hz}, 2 \mathrm{H}, o-\mathrm{H}^{\mathrm{Ts}}\right) .{ }^{13} \mathrm{C} \mathrm{NMR}(100$ $\left.\mathrm{MHz}, \mathrm{CDCl}_{3}\right) \delta_{\mathrm{C}}$ ppm: 15.10, 21.74, 66.88, 68.01, 69.45, 128.11, 129.91, 133.31, 144.87 .

1,2-Bis(2-ethoxyethoxy)benzene (3b). Catechol (2.20 g, 20 $\mathrm{mmol})$ was added to the suspension of $\mathrm{K}_{2} \mathrm{CO}_{3}(27.40 \mathrm{~g}, 0.2 \mathrm{~mol})$ in $50 \mathrm{ml} \mathrm{DMF}$, the mixture was flushed with argon and heated to $100{ }^{\circ} \mathrm{C}$. Tosylate $3 \mathrm{a}(12.2 \mathrm{~g}, 50 \mathrm{mmol})$ was added via the syringe through the septum and the mixture was vigorously stirred for 22 hours. After cooling to room temperature, the mixture was diluted with water and extracted with $\mathrm{CHCl}_{3}(3 \times 100 \mathrm{ml})$. The organic layers were washed with brine $(100 \mathrm{ml})$, dried over $\mathrm{Na}_{2} \mathrm{SO}_{4}$ and evaporated. The product was chromatographed on silica, using the mixture of chloroform with hexane (30-0 vol\%) as the eluent. Compound $\mathbf{3 b}$ was isolated as yellowish oil (4.04 g, $79 \%)$. ${ }^{1} \mathrm{H} \mathrm{NMR}(600 \mathrm{MHz}$, $\left.\mathrm{CDCl}_{3}\right) \delta_{\mathrm{H}} \mathrm{ppm}: 1.23\left(\mathrm{t}, J=7.0 \mathrm{~Hz}, 6 \mathrm{H}, \mathrm{CH}_{3}\right), 3.61$ (q, $J=7.0 \mathrm{~Hz}, 4 \mathrm{H}$, $\left.\mathrm{CH}_{2}{ }^{\mathrm{Et}}\right), 3.80$ (m, $\left.4 \mathrm{H},-\mathrm{OCH}_{2} \mathrm{CH}_{2} \mathrm{OEt}\right), 4.16$ (m, 4H, $\left.-\mathrm{OCH}_{2} \mathrm{CH}_{2} \mathrm{OEt}\right)$, 6.89-6.94 (m, $\left.4 \mathrm{H}, \mathrm{H}_{\mathrm{Ar}}\right) \cdot{ }^{13} \mathrm{C} \mathrm{NMR}\left(100 \mathrm{MHz}, \mathrm{CDCl}_{3}\right) \delta_{\mathrm{C}} \mathrm{ppm:} 15.36$, 66.94, 69.21, 69.23, 115.46, 121.85, 149.39 .

1,2-Dibromo-4,5-bis(2-ethoxyethoxy)benzene (3c). Compound $3 \mathbf{b}$ (4.04 g, $15.9 \mathrm{mmol}$ ) was dissolved in $30 \mathrm{ml}$ of DMF, solution of $N$-bromosuccinimide $(6.19 \mathrm{~g}, 34.9 \mathrm{mmol})$ in $30 \mathrm{ml}$ of DMF was added dropwise and the mixture was stirred for 2 days. The reaction mixture was diluted with $60 \mathrm{ml}$ of aqueous solution of $\mathrm{Na}_{2} \mathrm{SO}_{3}$, the solution was extracted with $\mathrm{CHCl}_{3}(3 \times 50 \mathrm{ml})$, organic layer was washed with water $(2 \times 50 \mathrm{ml})$, brine $(50 \mathrm{ml})$, dried over $\mathrm{Na}_{2} \mathrm{SO}_{4}$ and evaporated. The product was chromatographed on silica, using the mixture of hexane-EtOAc (7/3 vol.) as eluent. Dibromide 3c was isolated as viscous yellowish oil (5.98 g, $91 \%)$. ${ }^{1} \mathrm{H}$ NMR $\left(600 \mathrm{MHz}, \mathrm{CDCl}_{3}\right) \delta_{\mathrm{H}} \mathrm{ppm}: 1.22\left(\mathrm{t}, J=7.00 \mathrm{~Hz}, 6 \mathrm{H}, \mathrm{CH}_{3}\right), 3.58$ (q, $\left.J=7.00 \mathrm{~Hz}, 4 \mathrm{H}, \mathrm{CH}_{2}^{\mathrm{Et}}\right), 3.77$ (m, 4H, $\left.-\mathrm{OCH}_{2} \mathrm{CH}_{2} \mathrm{OEt}\right), 4.12$ (m, $4 \mathrm{H}$, $\left.-\mathrm{OCH}_{2} \mathrm{CH}_{2} \mathrm{OEt}\right), 7.15\left(\mathrm{~s}, 2 \mathrm{H}, \mathrm{H}_{\mathrm{Ar}}\right) \cdot{ }^{13} \mathrm{C} \mathrm{NMR}\left(100 \mathrm{MHz}, \mathrm{CDCl}_{3}\right) \delta_{\mathrm{C}}$ ppm: 15.31, 67.00, 68.93, 69.63, 115.53, 119.50, 149.18.

4,5-Bis(2-ethoxyethoxy)phthalonitrile (3d). Dibromide $\mathbf{3 c}$ (2.35 g, $5.7 \mathrm{mmol})$ was placed into the flask, followed by $\mathrm{Zn}(\mathrm{CN})_{2}$ (998 mg, $8.5 \mathrm{mmol}$ ), $\mathrm{Pd}_{2}(\mathrm{dba})_{3}(104 \mathrm{mg}, 0.11 \mathrm{mmol}$ ), dppf (88 mg, $0.15 \mathrm{mmol})$ and DMAA $(10 \mathrm{ml})$. The mixture was flushed with Ar three times and heated to $120{ }^{\circ} \mathrm{C}$ for $3 \mathrm{~h}$. After cooling to r.t., the reaction mixture was diluted with EtOAc, filtered throught the layer of $\mathrm{SiO}_{2}$, the solids were washed with EtOAc and the filtrate was evaporated, resulting in dark-orange solid. The product was chromatographed on silica, using the mixture of EtOAc and hexane (80-60 vol.\%) as the eluent. After recrystallization from $\mathrm{CHCl}_{3}$ / hexane mixture dinitrile $\mathbf{3 d}$ was isolated as a white crystalline solid $(1.38 \mathrm{~g}, 80 \%)$. ${ }^{1} \mathrm{H}$ NMR $\left(600 \mathrm{MHz}, \mathrm{CDCl}_{3}\right) \delta_{\mathrm{H}} \mathrm{ppm}: 1.22(\mathrm{t}$, $\left.J=7.00 \mathrm{~Hz}, 6 \mathrm{H}, \mathrm{CH}_{3}\right), 3.59$ (q, $\left.J=7.00 \mathrm{~Hz}, 4 \mathrm{H}, \mathrm{CH}_{2}{ }^{\mathrm{EH}}\right), 3.83(\mathrm{~m}, 4 \mathrm{H}$, $\left.-\mathrm{OCH}_{2} \mathrm{CH}_{2} \mathrm{OEt}\right), 4.23\left(\mathrm{~m}, 4 \mathrm{H},-\mathrm{OCH}_{2} \mathrm{CH}_{2} \mathrm{OEt}\right), 7.24\left(\mathrm{~s}, 2 \mathrm{H}, \mathrm{H}_{\mathrm{Ar}}\right)$. ${ }^{13} \mathrm{C} \mathrm{NMR}^{2}\left(100 \mathrm{MHz}, \mathrm{CDCl}_{3}\right) \delta_{\mathrm{C}} \mathrm{ppm}: 15.25,67.19,68.66,69.71$, 109.02, 115.89, 117.29, 152.66.

4',5',4",5"-Tetrabromodibenzo-24-crown-8 (4a). Dibenzo24-crown-8 (5.00 g, $11 \mathrm{mmol})$ was dissolved in $50 \mathrm{ml}$ of dry DMF and NBS ( $8.74 \mathrm{~g}, 49 \mathrm{mmol})$ was added. After stirring for 2 days, the solution was diluted with $150 \mathrm{ml}$ of water. The formed precipitate was filtered and washed with water. The residue was recrystallized from ethanol to produce the pure tetrabromide $4 \mathrm{a}(7.07 \mathrm{~g}, 85 \%)$. ${ }^{1} \mathrm{H}$ NMR $\left(600 \mathrm{MHz}, \mathrm{CDCl}_{3}\right) \delta_{\mathrm{H}} \mathrm{ppm}: 3.79\left(\mathrm{~s}, 8 \mathrm{H}, \gamma-\mathrm{CH}_{2}\right), 3.89(\mathrm{t}, 8 \mathrm{H}$, $\left.{ }^{3} J=4.2, \beta-\mathrm{CH}_{2}\right), 4.10\left(\mathrm{t}, 8 \mathrm{H},{ }^{3} J=4.2, \alpha-\mathrm{CH}_{2}\right), 7.06\left(\mathrm{~s}, 4 \mathrm{H}, \mathrm{H}_{\mathrm{Ar}}\right) \cdot{ }^{13} \mathrm{C}$ NMR $\left(100 \mathrm{MHz}, \mathrm{CDCl}_{3}\right) \delta_{\mathrm{C}}$ ppm: $69.66\left(\beta-\mathrm{CH}_{2}\right), 69.82\left(\alpha-\mathrm{CH}_{2}\right)$, $71.34\left(\gamma-\mathrm{CH}_{2}\right), 115.27(\mathrm{C}-\mathrm{Br}), 118.48\left(\mathrm{CH}_{\mathrm{Ar}}\right), 148.84\left(\mathrm{C}_{\mathrm{Ar}}-\mathrm{O}\right)$.

4',5',4",5"-Tetracyanodibenzo-24-crown-8 (4b). Tetrabromide 4a (1.00 g, $1.3 \mathrm{mmol}), \mathrm{Pd}_{2}(\mathrm{dba})_{3}(48 \mathrm{mg}, 0.052 \mathrm{mmol}), \mathrm{dppf}$ (39 mg, $0.070 \mathrm{mmol})$ and $\mathrm{Zn}(\mathrm{CN})_{2}(456 \mathrm{mg}, 3.9 \mathrm{mmol})$ were mixed as solids and flushed with Ar. Then DMAA (5 ml) was added and the mixture was heated to $120^{\circ} \mathrm{C}$ for $4.5 \mathrm{~h}$. Then the reaction mixture was cooled to ambient temperature, resulting in its solidification. $\mathrm{CHCl}_{3}(10 \mathrm{ml})$ was added and resulting suspension was filtered. The filtrate was evaporated to dryness and resulting solid was suspended in $\mathrm{MeOH}$ $(15 \mathrm{ml})$, refluxed for $1 \mathrm{~h}$, cooled to r. t., filtered and the precipitate was dried in vacuo, yielding tetranitrile $4 \mathrm{~b}$ as grayish solid (442 mg, yield $77 \%$ ). ${ }^{1} \mathrm{H}$ NMR $\left(600 \mathrm{MHz}, \mathrm{CDCl}_{3} / \mathrm{MeOD}=3 / 1\right) \delta_{\mathrm{H}} \mathrm{ppm}: 3.79(\mathrm{~s}, 8 \mathrm{H}$, $\left.\gamma-\mathrm{CH}_{2}\right), 3.93\left(\mathrm{t}, 8 \mathrm{H},{ }^{3} \mathrm{~J}=4.0, \beta-\mathrm{CH}_{2}\right), 4.21\left(\mathrm{t}, 8 \mathrm{H},{ }^{3} \mathrm{~J}=4.1, \alpha-\mathrm{CH}_{2}\right)$, $7.15\left(\mathrm{~s}, 4 \mathrm{H}, \mathrm{H}_{\mathrm{Ar}}\right) .{ }^{13} \mathrm{C} \mathrm{NMR}\left(100 \mathrm{MHz}, \mathrm{CDCl}_{3} / \mathrm{MeOD}=3 / 1\right) \delta_{\mathrm{C}} \mathrm{ppm}:$ $69.37\left(\beta-\mathrm{CH}_{2}\right), 69.94\left(\alpha-\mathrm{CH}_{2}\right), 71.58\left(\gamma-\mathrm{CH}_{2}\right), 109.01(C-\mathrm{CN}), 115.62$ $(\mathrm{CCN}), 116.35\left(\mathrm{CH}_{\mathrm{Ar}}\right), 152.19\left(\mathrm{C}_{\mathrm{Ar}}-\mathrm{O}\right)$. 


\section{Results and Discussion}

By the moment, only rare examples of transition-metal catalyzed synthesis of aromatic $o$-dinitriles are presented in the literature. Similar to Rosenmund-Braun cyanation, in the case of catalytic cyanodehalogenation introduction of the first cyano-group in the ortho-position to the exchangeable halogen significantly decreases its reactivity, therefore these reactions require very efficient catalytic systems.

For example, cyanation of chloroarenes by $\mathrm{KCN}$ can be catalyzed by $\mathrm{Ni}\left(\mathrm{PPh}_{3}\right)_{2} \mathrm{Br}_{2}$ and $\mathrm{Zn}$ powder in acetonitrile or hexamethylphosphoramide (HMPA), as reported in 1988 by Sakakibara et al. ${ }^{[27]}$ The authors demonstrated that this catalytic system is efficient for cyanation of wide range of mono-halogenated substrates, bearing both electrondonating and withdrawing substituents. However, in the case of $o$-dichlorobenzene the conversion was only $11 \%$, yielding mixture of mono- and disubstitution products. Under the same conditions, $O$-chlorobenzonitrile was converted into phthalonitrile only by $20 \%$ in $\mathrm{CH}_{3} \mathrm{CN}$ and $29 \%$ in HMPA, while $m$ - and $p$-chlorobenzonitriles furnished $76 \%$ and 96 $\%$ of corresponding dinitriles upon cyanation in $\mathrm{CH}_{3} \mathrm{CN}$. Notably, when 1,1'-diphenylphosphinoferrocene (dppf) was used instead of $\mathrm{PPh}_{3}, O$-chlorobenzonitrile could be converted into phthalonitrile with $94 \%$ conversion and 87 $\%$ selectivity.

Because of high toxicity of $\mathrm{KCN}$, many efforts were made to replace it with less dangerous sources of cyanidegroup. One of the most promising substitutes for $\mathrm{KCN}$ reported so far is nontoxic potassium hexacyanoferrate(II) proposed by Beller et al. in 2004. ${ }^{[28]}$ Initially, $\mathrm{Pd}(\mathrm{OAc})_{2}$ catalyst and dppf ligand were used for cyanation of various brominated arenes and heteroarenes by $\mathrm{K}_{4}\left[\mathrm{Fe}(\mathrm{CN})_{6}\right]$. Later in 2007, this group developed novel bio-mimetic system for catalytic cyanation, namely $\mathrm{CuI}(10$ vol.\%) and N-methylor N-butylimidazole (2 eq.) as ligands. ${ }^{[29]}$ Wide range of substrates was studied, among them - o-dibromobenzene, which was converted into phthalonitrile in $78 \%$ yield. Surprisingly, only very few papers report about synthesis of phthalonitriles via this promising protocol.

For example, this reaction was applied to prepare 5,6-dicyano-1,1,3,3-tetramethylisoindoline, which was subsequently hydrolized to give corresponding phthalic acid derivative as a precursor to water-soluble nitroxide radicals ${ }^{[30]}$ or conformationally unambiguous spin labels for distance measurements $^{[31]}$ (Figure 4).

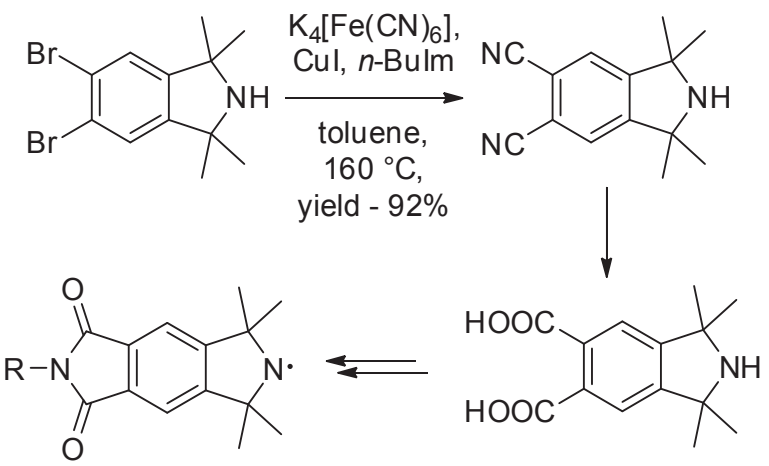

Figure 4. Cu-catalyzed cyanation of 5,6-dibromo-1,1,3,3tetramethylisoindoline. ${ }^{[31,30]}$
The rest of reports, dealing with catalytic preparation of phthalonitriles, refer to Pd-catalyzed reactions. For example, Barrett et al. used such type of reaction to prepare phthalonitrile with nitroxide group (Figure 5). Treatment of corresponding dibromide with zinc cyanide (2.4 eq.) and $\mathrm{Pd}\left(\mathrm{PPh}_{3}\right)_{4}(0.5$ eq. $)$ as a catalyst in DMF at mild conditions $\left(85{ }^{\circ} \mathrm{C}, 5 \mathrm{~h}\right)$ yielded target nitrile in excellent yield $(95$ $\%) \cdot{ }^{[32]}$ When Rosenmund-Braun cyanation was used for the same purpose, only $29 \%$ of target dinitrile was isolated, as well as minor amounts of monocyanated product. Therefore, the authors demonstrated that the presence of the radical moiety did not interfere with $\operatorname{Pd}(0)$-catalyzed coupling.

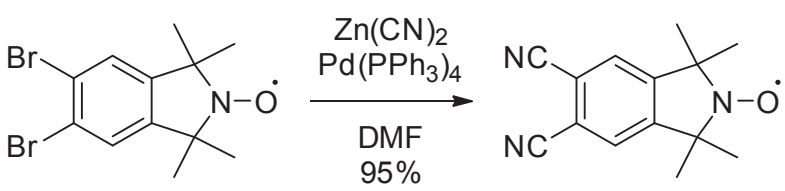

Figure 5. Pd-catalyzed synthesis of 5,5,7,7-tetramethylpyrrolo$[3,4-f]$ isoindole-1,3-diylidenediamin-6-yloxyl. ${ }^{[32]}$

Cyanation of diesters of 4,5-dichlorophthalic acid was performed by Tylleman et al. via reaction with $\mathrm{Zn}(\mathrm{CN})_{2}$ (1.2 eq.), $\mathrm{Pd}_{2}(\mathrm{dba})_{3}(4 \mathrm{~mol} \%$ ), dppf (6 mol.\%) and $\mathrm{Zn}$ powder (20 mol.\%) in N,N-dimethylacetamide (Figure 6). [33] Zinc metal was used to prevent the catalyst from deactivation. Target dinitriles were obtained in 72-83\% yields after 2 hours of heating of reaction mixtures at 120 ${ }^{\circ} \mathrm{C}$. In course of reaction, the authors noticed the appearance of green coloration, attributed to the formation of zinc phthalocyaninates. If the reaction mixture was heated to 140 ${ }^{\circ} \mathrm{C}$ for 16 hours, some amounts of zinc phthalocyaninates could be isolated by chromatography $(13 \%$ for $\mathrm{R}=$ ethyl and $6 \%$ for $\mathrm{R}=2$-butyloctyl). To increase the yield, step-wise one-pot procedure was tested - firstly, the reaction mixture was heated to $120^{\circ} \mathrm{C}$ for 2 hours and then DBU was added and the reaction mixture was heated to $140{ }^{\circ} \mathrm{C}$ for 16 hours, but it resulted only in marginal improvement of the yield of the isolated phthalocyaninate $(10 \%, \mathrm{R}=2$-butyloctyl). To explain this, the authors assumed that under the experimental conditions the cleavage of ester groups could occur, leading to the formation of highly polar products which could not be eluted from the chromatographic column, resulting in low yields of isolated phthalocyanines.

To prepare 4,5-dibromophthalonitrile, $\mathrm{Pd}(\mathrm{PPh})_{3}$ catalyzed cyanation was studied on the example of 1,2diiodo-4,5-dibromobenzene. ${ }^{[34]}$ Variation of reaction conditions (source of cyanides, introduction of additives, temperature, reagent ratios, etc.) revealed the most efficient catalytic system, which affords selective substitution of iodine atoms (2.4 eq. of $\mathrm{Zn}(\mathrm{CN})_{2}, 0.01$ eq of $\mathrm{Pd}\left(\mathrm{PPh}_{3}\right)_{4}$, addition of 1 eq of pyridine, Figure 7 ), yielding $73 \%$ of target dinitrile. Its Sonogashira coupling with $t$-butyldimethylsilylacetylene and subsequent $\mathrm{Zn}$-templated cyclotetramerization of resulting nitrile afforded corresponding octasubstituted Zn phthalocyaninate, whose periphery can be modified by means of "click-chemistry" reactions.

Apart from halogen substitution, aromatic nitriles can be prepared by Pd-catalyzed substitution of triflate 
<smiles>[R]OC(=O)c1cc(Cl)c(Cl)cc1C(=O)O[R]</smiles>

1. $\mathrm{Zn}(\mathrm{CN})_{2}, \mathrm{Pd}_{2}(\mathrm{dba})_{3}$ dppf, Zn, DMAA, $120^{\circ} \mathrm{C}$

2. $\mathrm{DBU}, 140^{\circ} \mathrm{C}$

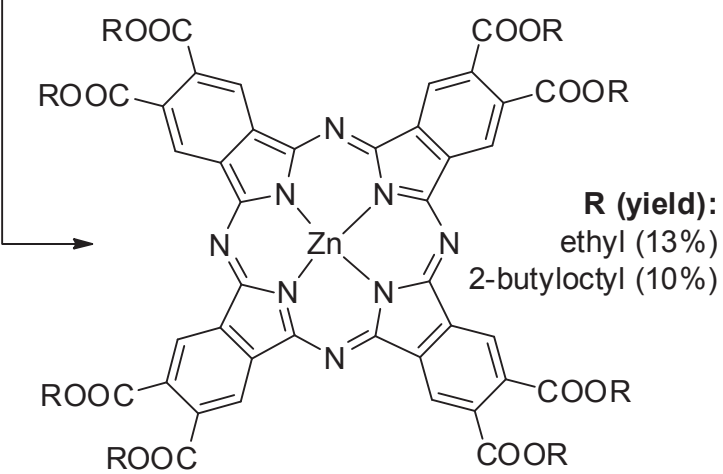

Figure 6. Pd-catalyzed synthesis of cyanated dialkylphthalates and one-pot synthesis of zinc phthalocyaninates. ${ }^{[33]}$

groups. ${ }^{[24]}$ This type of reactions was adapted by the group of Prof. M. Hanack for the preparation of phthalonitriles from triflated $o$-dihydroxyarenes and this method was tested on several triflated catechols - both peripherally and nonperipherally substituted, bearing alkane chains, ester groups, protected aminoacid residues, as well as di-O-triflate of 2,3-dihydroxynaphthalene (Figure 8). ${ }^{[35,36]}$ The ditriflates
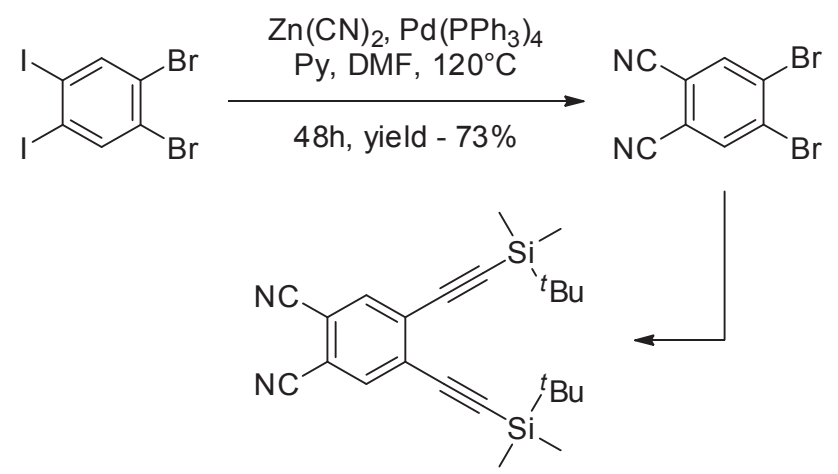

were prepared in high yields by treatment of corresponding substrates with $\mathrm{Tf}_{2} \mathrm{O}$ and $\mathrm{Et}_{3} \mathrm{~N}$ in $\mathrm{CH}_{2} \mathrm{Cl}_{2}$. Reactions of ditriflates with $\mathrm{Zn}(\mathrm{CN})_{2}$ (1.2 eq.), $\mathrm{Pd}_{2}(\mathrm{dba})_{3}(4 \mathrm{~mol} . \%)$ and dppf $(16 \mathrm{~mol} . \%)$ in DMF at $60-90{ }^{\circ} \mathrm{C}$ resulted in smooth formation of target dinitriles in $75-90 \%$ yields. The obtained phthalonitriles were used to synthesize phthalocyanines for photodynamic therapy. ${ }^{[36]}$

To maintain low concentration of cyanide in solution, $\mathrm{Zn}(\mathrm{CN})_{2}$, should be added to the reaction mixture in small portions (15-20 portions over 2 hours). If all $\mathrm{Zn}(\mathrm{CN})_{2}$ is added at once, then no phthalonitrile could be obtained, because in this case excess of free cyanide-ion sequesters Pd catalyst. ${ }^{[37]}$

Pd-catalyzed cyanation was also applied to prepare polycyanated compounds - precursors to olygomeric phthalocyanines. Thus, Hanack et al. performed treatment of hexabromotriphenylene with $\mathrm{KCN}$ in the presence of 18crown-6 and $\mathrm{Pd}\left(\mathrm{PPh}_{3}\right)_{4}$ in 2-chloronaphthalene (2-CIN). ${ }^{[38]}$ It yielded desired product of hexasubstitution in $41 \%$ (Figure 9). However, this hexanitrile turned out to be almost insoluble in common organic solvents due to its planarity, resulting in problems of carrying out its self-condensation reaction.

To improve the solubility of polycyanated precursor, the authors chose nonplanar tribenzylene scaffold which contains three aromatic rings, separated with three methylene bridges (Figure 10). ${ }^{[38]}$ For this purpose, the well-known and readily available cyclic host - cyclotriveratrylene, ${ }^{[39,40]}$ was treated with $\mathrm{BBr}_{3}$ to produce corresponding tris-catechol, which was further treated with nonaflyl fluoride $\left(n-\mathrm{C}_{4} \mathrm{~F}_{9} \mathrm{SO}_{2} \mathrm{~F}, \mathrm{NfF}\right)$ and $\mathrm{NEt}_{3}$ in DMF to obtain hexa-nonaflyl-derivative. Stepwise addition of $\mathrm{Zn}(\mathrm{CN})_{2}$ and $\mathrm{Pd}\left(\mathrm{PPh}_{3}\right)_{4}$ to the solution of this hexa-nonaflate in DMF at $85{ }^{\circ} \mathrm{C}$ afforded desired hexanitrile in $32 \%$ yield.

To prepare first example of gable bis-phthalocyanine, Kobayashi et al. synthesized tetracyanated compound, based on bicyclo[2.2.2] octane scaffold, which provides oblique arrangement of phthalonitrile units (Figure 11). ${ }^{[41]}$ For this purpose, the product of Diels-Alder cycloaddition of cis-2-butene-1,4-diol to anthracene was brominated with molecular bromine in the presence of catalytic amount of iodine. Resulting tetrabromide was treated with $\mathrm{KCN}$ (4.6 eq.) and $\mathrm{Pd}\left(\mathrm{PPh}_{3}\right)_{4}(0.6$ eq. $)$ in refluxing $\mathrm{DMF}$, yielding target tetranitrile in $52 \%$ yield. The attempt to prepare this compound by Rosenmund-Braun reaction afforded mixture of mono-, di- and trinitriles with less than $0.1 \%$ of desired tetranitrile. Li-templated condensation of resulting tetranitrile with excess of 4-tert-butylphthalonitrile ${ }^{[41]}$ and subsequent metallation with $\mathrm{Zn}(\mathrm{OAc})_{2}$ afforded gable bisphthalocyaninate, ${ }^{[42]}$ which could be converted into planar bis-phthalocyaninate containing a shared anthracene unit with extended near-IR absorption.

Figure 7. Synthesis of dibromo- and di-TBDMSalkinylphthalonitriles. ${ }^{[34]}$<smiles>[R3]c1cc(C#N)c(C#N)c([R])c1[R2]</smiles>

Figure 8. Pd-catalyzed synthesis of phthalonitriles from triflated catechols: (a) $\mathrm{R}_{1}=\mathrm{CH}_{3}, \mathrm{R}_{2}=\mathrm{R}_{3}=\mathrm{H}$; (b) $\mathrm{R}_{1}=\mathrm{R}_{2}=\mathrm{H}_{1} \mathrm{R}_{3}=\mathrm{CH}_{3} ;\left(\right.$ c) $\mathrm{R}_{1}=\mathrm{R}_{2}=$ $\mathrm{H}, \mathrm{R}_{3}=\mathrm{COOEt}$; (d) $\mathrm{R}_{1}=\left(\mathrm{CH}_{2}\right)_{4} \mathrm{COOMe}, \mathrm{R}_{2}=\mathrm{R}_{3}=\mathrm{H} ;($ e $) \mathrm{R}_{1}=\mathrm{R}_{2}=\mathrm{H}, \mathrm{R}_{3}=\mathrm{CH}_{2} \mathrm{CH}(\mathrm{NHBOc})$ COOMe; $(f) \mathrm{R}_{1}=\mathrm{H}_{2}, \mathrm{R}_{2}=\mathrm{R}_{3}=\mathrm{CH}_{2} \mathrm{CH}_{2} \mathrm{COOEt}$; (g) $\mathrm{R}_{1}=\mathrm{H}, \mathrm{R}_{2}, \mathrm{R}_{3}=-\mathrm{CHCH}-\mathrm{CHCH}-.^{[35]}$ 
<smiles>Brc1cc2c3cc(Br)c(Br)cc3c3cc(Br)c(Br)cc3c2cc1Br</smiles>

$\mathrm{KCN}, 18-$ crown-6 $\mathrm{Pd}\left(\mathrm{PPh}_{3}\right)_{4}, 2-\mathrm{CIN}$ yield $-41 \%$<smiles>N#Cc1cc2c3cc(C#N)c(C#N)cc3c3cc(C#N)c(C#N)cc3c2cc1C#N</smiles>

To prepare dimeric phthalocyanine with [2.2] paracyclophane bridge, 4,5,12,13-tetrabromo[2.2]paracyclophane was treated with mixture of $\mathrm{CuCN}$ (4.4 eq.) and $\mathrm{CuI}(5.5 \mathrm{~mol} . \%)$ in the presence of $\mathrm{Pd}\left(\mathrm{PPh}_{3}\right)_{4}(60 \mathrm{~mol} . \%)$ and N,N-dimethylethylenediamine (DMEDA, $20 \mathrm{~mol} \%$ ) in diglyme (Figure 12). ${ }^{[43]}$ Under these conditions coppercatalyzed substitution of bromine with iodine occurs, ${ }^{[4]}$ with subsequent Pd-catalyzed cyanation, which altogether affords target tetranitrile in $51 \%$ yield. Copper or zinctemplated cross-condensation of this tetranitrile with excess of tert-butyl-phthalonitrile afforded dimeric phthalocyanines with efficient transannular interaction in the excited singlet states.
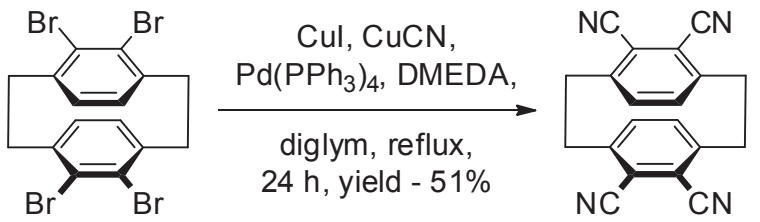

Figure 12. Synthesis of 4,5,12,13-tetracyano[2.2]-paracyclophane. ${ }^{[43]}$

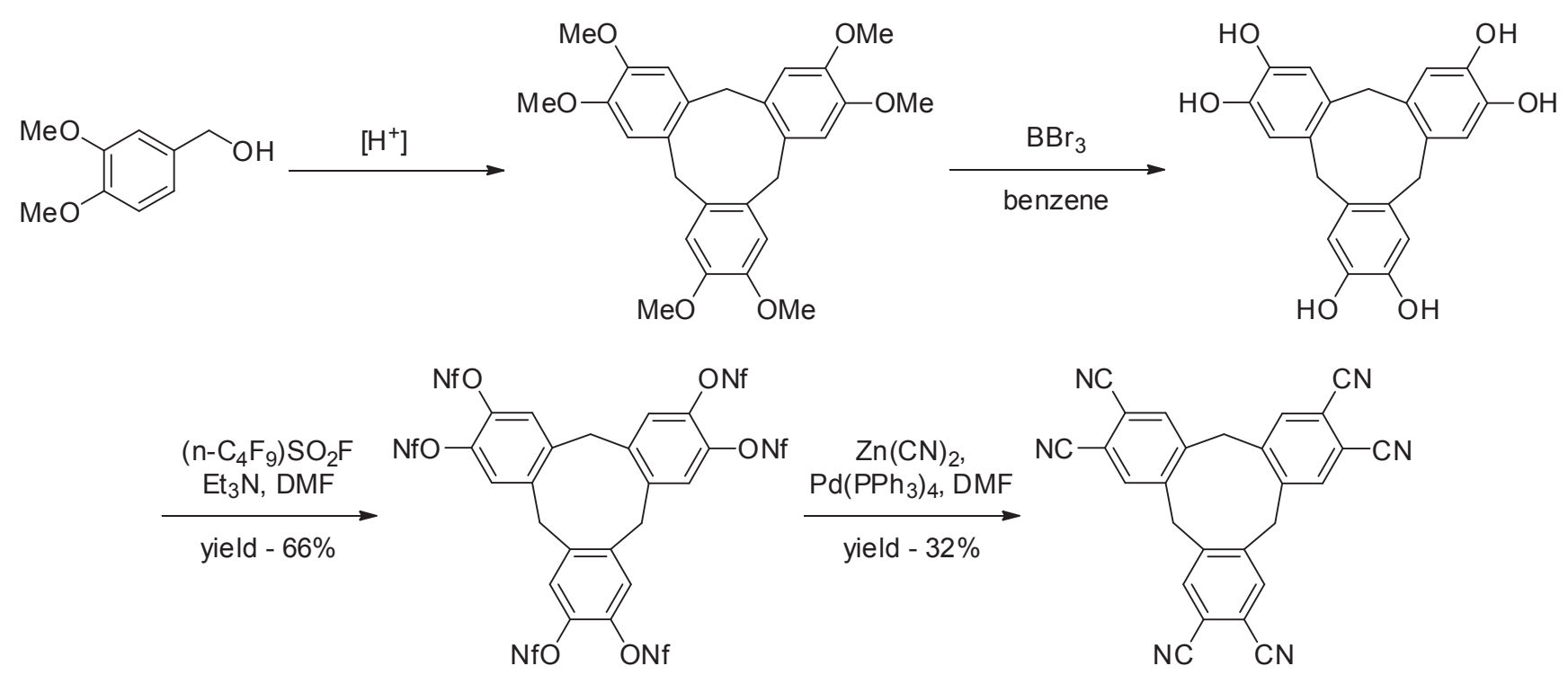

Figure 10. Synthesis of 2,3,7,8,12,13-hexacyanotribenzylene. ${ }^{[38]}$<smiles>OC/C=C\CO</smiles><smiles></smiles><smiles>OCC1C2c3ccccc3C(c3ccccc32)C1CO</smiles><smiles>Brc1cc2c(cc1Br)C1c3cc(Br)c(Br)cc3C2C2COCC12</smiles>

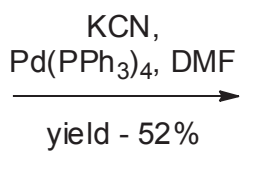<smiles>N#Cc1cc2c(cc1C#N)C1c3cc(C#N)c(C#N)cc3C2C2COCC12</smiles>

Figure 11. Synthesis of tetranitrile - precursor to gable bis-phthalocyanine. ${ }^{[41]}$ 
Altogether, the abovementioned examples of transitionmetal catalyzed cyanation of aromatic $o$-dihalogenides and analogues (fluorinated sulfonates) evidence of high potential of this family of reactions. However, for the long time no general methodology for the preparation of phthalonitriles was available and the excising methods sometimes required almost equivalent loadings of relatively expensive $\mathrm{Pd}$ catalysts.

In 2008 the group of Hanack has developed novel general method of $\mathrm{Pd}$-catalyzed preparation of $o$-dinitriles starting from $o$-dibromobenzenes, which are more readily available compounds than triflated catechols. ${ }^{[45]}$

For this purpose, $\mathrm{Zn}(\mathrm{CN})_{2}$ (1 eq.) was used as a source of cyanide-group, and only $2 \mathrm{~mol} \%$ of $\mathrm{Pd}_{2}(\mathrm{dba})_{3}$ and 2.7 mol.\% of dppf were used as a catalytic system. Heating of reaction mixtures in DMAA at $100-120^{\circ} \mathrm{C}$ typically for $2-3$ hours furnished target dinitriles in excellent yields. Notably, phthalocyanine formation was not observed in these reactions and no oxidative treatment of the reaction mixture was requires, opposite to classical Rosenmund-Braun cyanation. Moreover, the authors found reaction conditions which afforded performing this reaction in air. For this purpose, they added small amounts of polymethylhydrosiloxane (PMHS) to the reaction mixture. Previously, this polymer was found to protect $\operatorname{Pd}(0)$ species from air oxidation. ${ }^{[46]}$

Wide range of substrates was cyanated under these conditions, including 2,3-dibromopyridine and 2,3dibromonaphthalene (Figure 13). It was demonstrated, that in the case of fluorinated dibromobenzenes fluorine atoms do not undergo substitution. The presence of strong electron acceptor nitro-group in the molecule does not afford substitution of bromine in $p$-position - in the case of 3-nitro-4-amino-1,2-dibromobenzene only monocyanated product was obtained in $62 \%$ yield, while 3,4-dinitro-1,2dibromobenzene does not react at all. However, cyanation of 4,5-dicyano-1,2-dibromobenzene afforded $73 \%$ of tetracyanobenzene. The same product was obtained when cyanation of 1,2,4,5-tetrabromobenzene was performed (yield $72 \%$ ). In the case of dibromophenol, 4-hydroxyphthalonitrile was obtained in $89 \%$ yield, but dibromocatechol could not be cyanated, apparently because of formation of inert complexes with Pd.

By the moment, this work is the only systematic investigation of Pd-catalyzed cyanation of $o$-dibromoarenes, which gives wide possibilities for preparation of functionalized phthalonitriles as precursors to novel phthalocyanines.

Taking the advances of this powerful protocol, we have recently synthesized phthalonitrile $\mathbf{1 b}$, bearing diethyleneglycol chains, terminated with hydroxy-groups, starting from 1,2-dibromo-4,5-bis[2'-(2"-hydroxyethoxy)ethoxy]benzene 1a (Figure 14). ${ }^{[25]}$

Interest in dinitrile $\mathbf{1 b}$ arose previously since it is a promising precursor to phthalonitriles, bearing macrocyclic coordinating fragments. Dibromide 1a does not undergo cyanation under Rosenmund-Braun conditions because of the presence of free $\mathrm{OH}$-groups, therefore, some alternative strategies were proposed to prepare $\mathbf{1 b}$, however their implementation was also unsuccessful. For example, attempt of alkylation of dicyanocatechol with chloroethoxyethanol by Torres et al., failed to produce workable amount of $\mathbf{1 b}$ because of the strong electron-withdrawing effect of the cyano-groups. ${ }^{[19]}$ We also previously took an attempt to prepare $\mathbf{1 b}$ by cyanation of 4,5-dibromo-4,5-bis[2'-(2"benzyloxyethoxy)-ethoxy]benzene $\mathbf{2 a}$ and subsequent debenzylation $\left(\mathrm{H}_{2}, \mathrm{Pd} / \mathrm{C}\right)$ of resulting dinitrile $\mathbf{2} \mathbf{b} .^{[16]}$ It was demonstrated that phthalonitrile unit, which is present in $\mathbf{2} \mathbf{b}$, poisons $\mathrm{Pd} / \mathrm{C}$ catalyst and precludes deprotection of benzyl groups.

Then, Pd-catalyzed cyanation, proposed by Hanack et al. ${ }^{[45]}$ was applied to prepare dinitrile $\mathbf{1 b}$ (Figure 14). ${ }^{[25]}$ Performing this reaction exactly under reported conditions, namely, in air, in the presence of PMHS with portionwise addition of $\mathrm{Zn}(\mathrm{CN})_{2}$ resulted in low conversion $(\sim 15 \%)$ of $\mathbf{1 a}$ into $\mathbf{1 b}$. However, when all reagents were mixed at a time, DMAA was added, mixture was flushed with argon and reaction was performed under inert atmosphere, dinitrile 1b was obtained in excellent yield of $85 \%$. Probably, high sensitivity of this reaction to air can be explained<smiles>[R]c1cc(Br)c(Br)cc1[R2]</smiles><smiles>N#Cc1cc(Br)c(Br)cc1C#N</smiles><smiles>Brc1cc(Br)c(Br)cc1Br</smiles><smiles>C=C</smiles><smiles>C1CCCC1</smiles><smiles>N#Cc1cc(C#N)c(C#N)cc1C#N</smiles><smiles>Brc1cccnc1Br</smiles><smiles>N#Cc1cccnc1C#N</smiles><smiles>CC1(C)Oc2cc3cc(Br)c(Br)cc3cc2O1</smiles><smiles>CC1(C)Oc2cc3cc(C#N)c(C#N)cc3cc2O1</smiles><smiles>Nc1cc(Br)c(Br)cc1[N+](=O)[O-]</smiles><smiles>C1CCCCC1</smiles><smiles>N#Cc1cc([N+](=O)[O-])c(N)cc1Br</smiles><smiles>O=[N+]([O-])c1cc(Br)c([N+](=O)[O-])cc1Br</smiles><smiles>[Y][C@@H]1[CH]CC1</smiles><smiles>Oc1cc(Br)c(Br)cc1O</smiles>

Figure 13. Pd-catalyzed synthesis of phthalonitriles from $o$-dibromobenzenes. Reaction condtions: $\mathrm{Zn}(\mathrm{CN})_{2}, \mathrm{Pd}_{2}(\mathrm{dba})_{3}, \mathrm{dppf}, \mathrm{PMHS}$, DMAA, $100-120^{\circ} \mathrm{C} . \mathrm{R}_{1}, \mathrm{R}_{2}=\mathrm{H}$, Alk, OAlk, NHAc, OSi'BuMe ${ }_{2}$, F, etc. ${ }^{[45]}$ 
by the presence of free OH-groups, which may undergo side Pd-catalyzed processes under aerobic experimental conditions, ${ }^{[47,48]}$ resulting in loss of catalytic activity.

To confirm this hypothesis, dibromide $\mathbf{2 a}$ which contains benzylated $\mathrm{OH}$-groups, was introduced into Pd-catalyzed cyanation (Figure 14). Both in air in the presence of PMHS and under inert atmosphere, in both cases this reaction furnishing target dinitrile $\mathbf{2 b}$ in high yield (81\%), which was obtained after single chromatographic purification. When Rosenmund-Braun cyanation of $\mathbf{2} \mathbf{a}$ was made, it afforded $\mathbf{2 b}$ in satisfactory yield $(64 \%),{ }^{[16]}$ however, its isolation required tedious workup and numerous chromatographic purification steps. Phthalocyanines, prepared from $\mathbf{2 b}$ are expected to have mesogenic properties, ${ }^{[1]}$ as well as act as receptors for polyaromatic substrates and fullerenes. ${ }^{[49]}$

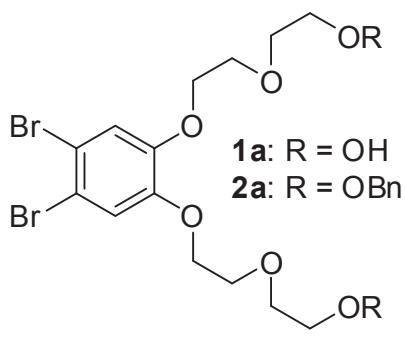

$$
\begin{aligned}
& \mathrm{Zn}(\mathrm{CN})_{2}, \mathrm{Pd}_{2}(\mathrm{dba})_{3} \\
& \text { dppf, DMAA, }
\end{aligned}
$$$$
120^{\circ} \mathrm{C}, 2.5 \mathrm{~h}, \mathrm{Ar}
$$<smiles>[R]OCCOCCOc1cc(C#N)c(C#N)cc1OCCOCCO[R]</smiles>

Figure 14. Pd-catalyzed synthesis of phthalonitriles, bearing unprotected and benzylated diethyleneglycol chains (yields $\mathbf{1 b}$ $85 \%{ }^{[25]}$ and $\mathbf{2 b}-81 \%$ ).

Notably, in the case of Pd-catalyzed cyanation, the reaction was sensitive to the purity of starting substrate $\mathbf{2 a}$ - cyanation was completely inhibited by trace amounts of dibromocatechol which could remain after preparation and chromatographic purification of $\mathbf{2 a}$, prepared by alkylation of dibromocatechol with tosylated 2-(2'-benzyloxyethoxy)ethanol. ${ }^{[16]}$
Cyanation of dibromide $3 \mathbf{c}$, bearing 2-(2'-ethoxy)ethoxyl groups, was also performed under anaerobic conditions. Dibromide $3 \mathbf{c}$ was directly mixed with $\mathrm{Pd}_{2}(\mathrm{dba})_{3}$, dppf and required amount of $\mathrm{Zn}(\mathrm{CN})_{2}$, reaction mixture was flushed with Ar, DMAA was added, and mixture heated to $120{ }^{\circ} \mathrm{C}$, which afforded dinitrile 3d in $80 \%$ yield (Figure 15). As a comparison, the yield of $\mathbf{3 d}$, obtained by Rosenmund-Braun reaction, was only $35 \% .{ }^{[50]}$ High solubility of phthalocyanines with ethoxyethyl substituents in polar solvents as well as efficient triplet state quenching by $\mathrm{O}_{2}$, producing singlet oxygen, makes possible their application in photodynamic therapy.

The efficiency of conversion of dibromides into dinitriles via Pd-catalyzed cyanation was also beneficial for preparation of polycyanated molecules. It was performed on the example of tetrabromide $\mathbf{4 a}$, which was prepared by treatment of dibenzo-24-crown-8 with $\mathrm{N}$-bromosuccinimide in DMF in $85 \%$ yield. Pd-catalyzed cyanation of $\mathbf{4 a}$ in the presence of only $4 \mathrm{~mol} \%$ of $\mathrm{Pd}_{2}(\mathrm{dba})_{3}$ afforded corresponding tetranitrile $4 \mathbf{b}$ in $77 \%$ yield (Figure 16). In this case, more prolonged heating $(4.5 \mathrm{~h})$ was required to provide complete fourfold substitution. Notably, no chromatography was required to isolate pure tetranitrile, since impurities (mostly, dppf) could be extracted from $\mathbf{4 b}$ by hot methanol. Tetranitrile $\mathbf{4 b}$ can be used to prepare dimeric phthalocyanines, which can be used as precursors to assemblies with rotaxane topology, ${ }^{[51,52]}$ as well as ionophoric polymers. ${ }^{[53,54]}$

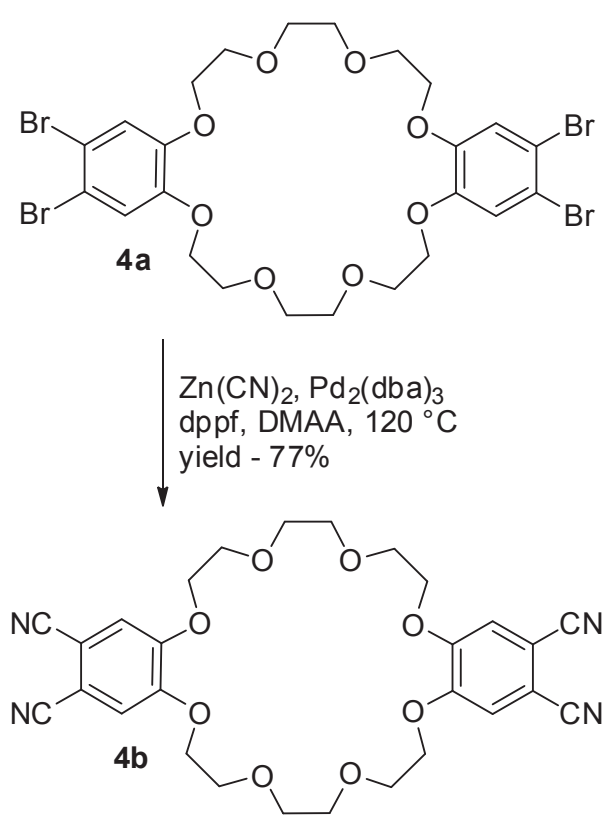

Figure 16. Synthesis of tetracyano-dibenzo-24-crown-8 $\mathbf{4 b}$.<smiles>CCOCCOc1ccc(OCCOCC)c(OCCOCC)c1</smiles><smiles>CCOCCOc1cc(Br)c(Br)cc1OCCOCC</smiles>

Figure 15. Synthesis of 4,5-bis(2-ethoxyethoxy)phthalonitrile 3d. 


\section{Conclusions}

Typical cyanation methodologies, applied for the preparation of phthalonitriles over last century ammonolysis/dehydratation strategy and, particularly, Rosenmund-Braun reaction, afforded numerous substituted phthalonitriles and analogues in yields, varying from low to fairly high. However, these methods fail to produce target compounds in cases, when the substituents are sensitive to reaction conditions.

Evolution of transition metal catalysed cyanation reac-tions afforded approaches to novel phthalonitriles, bearing labile functional groups (free radical centres, proton donors, etc.). Mild reaction conditions, easy workup and excellent yields evidence of high potential of catalytic approach in comparison with classical RosenmundBraun method. One can expect wider application of the above described methods as well as discovery of novel approaches towards phthalonitriles and analogues. Among them - application of non-toxic cyanide sources (for example, $\mathrm{K}_{4}\left[\mathrm{Fe}(\mathrm{CN})_{6}\right]$ instead of $\mathrm{KCN}, \mathrm{Zn}(\mathrm{CN})_{2}$, etc.) and replacement of relatively expensive $\mathrm{Pd}$ catalysts with $\mathrm{Cu}(\mathrm{I})$ complexes. Altogether, this may lead to synthesis of new phthalocyanines and molecular materials and devices on their basis.

Acknowledgements. This work was supported by RFBR grants 11-03-00968_a and 12-03-31366mol_a, grant MK1606.2013.3 and by Ministry of Education and Science of Russian Federation (agreement 8428).

\section{References}

1. McKeown N.B. In: The Porphyrin Handbook (Kadish K.M., Smith K.M., Guilard R., Eds.) New York: Academic Press, 2003, Vol. 15, 61-124.

2. Rodríguez-Morgade M.S., De la Torre G., Torres T. In: The Porphyrin Handbook (Kadish K.M., Smith K.M., Guilard R., Eds.) New York: Elsevier, 2003, Vol. 15, 125-160.

3. Wöhrle D., Schnurpfeil G., Makarov S.G., Kazarin A., Suvorova O.N., Macroheterocycles, 2012, 5, 191-202.

4. Gorbunova Y.G., Martynov A.G., Tsivadze A.Y. In: Handbook of Porphyrin Science (Kadish K.M., Smith K.M., Guilard R., Eds.) World Scientific Publishing, 2012, Vol. 24, 271-388.

5. Sharman W.M., Van Lier J.E. In: The Porphyrin Handbook (Kadish K.M., Smith K.M., Guilard R., Eds.) New York: Academic Press, 2003, Vol. 15, 1-60.

6. Wöhrle D., Eskes M., Shigehara K., Yamada A. Synthesis 1993, 194-196.

7. Terekhov D.S., Nolan K.J.M., McArthur C.R., Leznoff C.C., J. Org. Chem. 1996, 61, 3034-3040.

8. Aranyos V., Castaño A.M., Grennberg H., Hawthorne M.F., Sjöberg S., Tallec A., Shono T., Toftlund H. Acta Chem. Scand. 1999, 53, 714-720.

9. George R.D., Snow A.W. J. Heterocycl. Chem. 1995, 32, 495498.

10. Hopff H., Gallegra P. Helv. Chim. Acta 1968, 51, 253-260.

11. Drager A.S., O'Brien D.F. J. Org. Chem. 2000, 65, 22572260.

12. Jaquinod L., Khoury R.G., Shea K.M., Smith K.M., Tetrahedron 1999, 55, 13151-13158.

13. Ellis G.P., Romney-Alexander T.M. Chem. Rev. 1987, 87, 779794.
14. Minacheva L.K., Aleksandrov G.G., Lapkina L.A., Gorbunova Y.G., Demin S.V, Larchenko V.E., Sergienko V.S., Tsivadze A.Y. Russ. J. Coord. Chem. 2005, 31, 671-682.

15. Ivanov A.V., Svinareva P.A., Zhukov I.V., Tomilova L.G., Zefirov N.S. Russ. Chem. Bull., Int. Ed. 2003, 52, 1562-1566.

16. Martynov A.G., Gorbunova Y.G., Tsivadze A.Y., Sauvage J.-P. Mendeleev Commun. 2010, 20, 237-238.

17. Pardo C., Yuste M., Elguero J. J. Porphyrins Phthalocyanines 2000, 4, 505-509.

18. Burmester C., Faust R, Synthesi, 2008, 1179-1181.

19. Cabezón B., Quesada E., Esperanza S., Torres T. Eur. J. Org. Chem. 2000, 2767-2775.

20. Pushkarev V.E., Ivanov A.V., Zhukov I.V., Shulishov E.V., Tomilov Y.V. Russ. Chem. Bull., Int. Ed. 2004, 53, 554-560.

21. Barrett A.G.M., Broderick W.E., Hoffman B.M., Velazquez C.S. J. Org. Chem. 1989, 54, 3233-3234.

22. Anbarasan P., Schareina T., Beller M. Chem. Soc. Rev. 2011, 40, 5049-5067.

23. Beletskaya I.P., Selivanova A.V., Tyurin V.S., Matveev V.V., Khokhlov A.R. Russ. J. Org. Chem. 2010, 46, 157-161.

24. Tagaki K. In: Handbook of Organopalladium Chemistry for Organic Synthesis (Negishi E., Ed.) New York: John Wiley \& Sons, Inc., 2002, 657-672.

25. Martynov A.G., Gorbunova Y.G., Nefedov S.E., Tsivadze A.Y., Sauvage J.-P. Eur. J. Org. Chem. 2012, 6888-6894.

26. Fulmer G.R., Miller A.J.M., Sherden N.H., Gottlieb H.E., Nudelman A., Stoltz B. M., Bercaw J. E., Goldberg K.I., Organometallics 2010, 29, 2176-2179.

27. Sakakibara Y., Okuda F., Shimobayashi A., Kirino K., Sakai M., Uchino N., Takagi K. Bull. Chem. Soc. Jpn. 1988, 61, 1985-1990.

28. Schareina T., Zapf A., Beller M. Chem. Commun. 2004, 13881389.

29. Schareina T., Zapf A., Mägerlein W., Müller N., Beller M., Chem. Eur. J. 2007, 13, 6249-6254.

30. Fairfull-Smith K.E., Brackmann F., Bottle S.E. Eur. J. Org. Chem. 2009, 1902-1915.

31. Sajid M., Jeschke G., Wiebcke M., Godt A. Chem. Eur. J. 2009, 15, 12960-12962.

32. Barrett A.G.M., Hanson G.R., White A.J.P., Williams D.J., Micallef A.S. Tetrahedron 2007, 63, 5244-5250.

33. Tylleman B., Gómez-Aspe R., Gbabode G., Geerts Y.H., Sergeyev S. Tetrahedron 2008, 64, 4155-4161.

34. Jurícek M., Kouwer P.H.J., Rehák J., Sly J., Rowan A.E. J. Org. Chem. 2009, 74, 21-25.

35. Drechsler U., Hanack M. Synlett 1998, 1207-1208.

36. Drechsler U., Pfaff M., Hanack M. Eur. J. Org. Chem. 1999, 3441-3453.

37. Marcantonio K.M., Frey L.F., Liu Y., Chen Y., Strine J., Phenix B., Wallace D.J., Chen C. Org. Lett. 2004, 6, 3723-3725.

38. Krempl H., Mattmer R., Hanack M. Synthesis 2000, 17051708.

39. Collet A. Tetrahedron 1987, 43, 5725-5759.

40. Hardie M.J. Chem. Soc. Rev. 2010, 39, 516-527.

41. Asano Y., Kobayashi N. Tetrahedron Lett. 2004, 45, 95779580.

42. Asano Y., Sato J., Furuyama T., Kobayashi N. Chem. Commun. 2012, 48, 4365-4367.

43. Asano Y., Muranaka A., Fukasawa A., Hatano T., Uchiyama M., Kobayashi N. J. Am. Chem. Soc. 2007, 129, 4516-4517.

44. Zanon J., Klapars A., Buchwald S.L. J. Am. Chem. Soc. 2003, 125, 2890-2891.

45. Iqbal Z., Lyubimtsev A., Hanack M. Synlett 2008, 2287-2290.

46. Martin M.T., Liu B., Cooley B.E., Eaddy J.F. Tetrahedron Lett. 2007, 48, 2555-2557. 
Modern Synthetic Approaches to Phthalonitriles

47. Wang L.-Y., Li J., Lv Y., Zhang H.-Y., Gao S. J. Organomet. Chem. 2011, 696, 3257-3263.

48. Muzart J. Tetrahedron 2003, 59, 5789-5816.

49. Ray A., Santhosh K., Chattopadhyay S., Samanta A., Bhattacharya S. J. Phys. Chem. A 2010, 114, 5544-5550.

50. Foley S., Jones G., Liuzzi R., McGarvey D.J., Perry M.H., Truscott T.G. J. Chem. Soc., Perkin Trans. 2 1997, 17251730.

51. Martínez-Díaz M.V., Fender N.S., Rodríguez-Morgade M.S.,
Gómez-López M., Diederich F., Echegoyen L., Stoddart J.F., Torres T. J. Mater. Chem. 2002, 12, 2095-2099.

52. Guldi D.M., Ramey J., Martínez-Díaz M.V., De la Escosura A., Torres T., Da Ros T., Prato M. Chem. Commun. 2002, 2774-2475.

53. Ahsen V., Yilmazer E., Bekâroğlu Ö., Gül A. Macromol. Rapid Commun. 1987, 8, 243-246.

54. Ahsen V., Yilmazer E., Bekâroğlu Ö. Macromol. Chem. 1988, $189,2533-2543$.

Received 14.02.2013

Accepted 18.02.2013 